\title{
IMPLEMENTASI LESSON STUDY PADA MATA KULIAH KAPITA SELEKTA MATEMATIKA SMP UNTUK MENINGKATKAN HASIL BELAJAR MAHASISWA
}

\author{
Indah Puspita Sari ${ }^{1}$, Adi Nurjaman ${ }^{2}$ \\ 1,2 STKIP Siliwangi \\ ${ }^{1}$ chiva.aulia@gmail.com, ${ }^{2}$ hendrialfianto@gmail.com
}

\begin{abstract}
This research aims to improve the learning outcomes of students in the subject of Capita Selecta Mathematics in middle school through the implementation of Lesson Study. This research is a class action research in which the subject are the students of class A2 2014. The students are from regular class that consists of 41 students. The research was conducted in 4 cycle, in which each has 3 stages: plan, do, and see. Research data was obtained by observation and test. This research used a qualitative analysis consists of data reduction, data presentation and conclution. The result showed there was an increase learning outcomes of students in the subject of Capita Selecta Mathematics in middle school through the implementation of Lesson Study.
\end{abstract}

\begin{abstract}
ABSTRAK
Penelitian ini bertujuan untuk meningkatkan hasil belajar mahasiswa pada mata kuliah Kapita Selekta Matematika SMP melalui implementasi Lesson Study. Penelitian ini merupakan penelitian tindakan kelas dengan subjeknya adalah mahasiswa kelas A2 2014 Reguler yang berjumlah 41 mahasiswa. Penelitian ini dilakukan sebanyak 4 siklus, dimana setiap siklus terdiri dari 3 tahap yaitu plan, do, dan see. Data penelitian diperoleh dengan cara observasi dan tes. Analisis data yang digunakan dalam penelitian ini adalah analisis kualitatif yang terdiri dari reduksi data, penyajian data dan penarikan kesimpulan. Hasil penelitian menunjukkan terdapat peningkatan hasil belajar mahasiswa pada mata kuliah Kapita Selekta Matematika SMP melalui implementasi Lesson Study.
\end{abstract}

Kata Kunci: Lesson Study, Hasil Belajar

\section{Pendahuluan}

Mata kuliah Kapita Selekta Matematika terbagi menjadi beberapa bagian, yaitu Kapita Selekta Matematika SD, SD Lanjut, SMP dan SMA. Mata kuliah ini merupakan mata kuliah yang harus ditempuh oleh mahasiswa sebagai bekal mereka untuk menjadi seorang guru. Dalam mata kuliah Kapita Selekta Matematika SMP, materi yang dibahas merupakan materi-materi esensial pada kelas VII sampai dengan kelas IX Sekolah Menengah Pertama. Konsep matematika SMP yang baik perlu dimiliki oleh mahasiswa karena merupakan dasar dalam pembelajaran matematika. Jika mahasiswa tidak memiliki konsep SMP yang baik, maka akan berimplikasi pada pembelajaran matematika selanjutnya.

Berdasarkan pengalaman peneliti pada semestersemester sebelumnya, hasil belajar mahasiswa pada mata kuliah Kapita Selekta Matematika kurang memuaskan. Hal ini dikarenakan, pada saat proses pembelajaran mahasiswa lebih sering mendengarkan penjelasan dari dosen. Proses pembelajaran seperti ini akan mengakibatkan 
mahasiswa menjadi kurang aktif dan materimateri esensial tidak mereka terima seutuhnya sehingga hasil belajar mahasiswa kurang optimal. Seperti yang dikemukakan oleh Anggraeni (2008:5) bahwa sikap dan kebiasan belajar yang baik akan memberikan tunjangan terhadap pencapaian hasil belajar yang optimal dan sebaliknya sikap dan kebiasaan belajar yang kurang baik, kurang ulet, dan kurang gesit akan mempengaruhi hasil belajar yang tidak optimal.

Lesson Study merupakan salah satu alternatif untuk memperbaiki sikap dan kebiasaan belajar mahasiswa selama ini. Lesson Study pertama kali dikembangkan oleh para guru pendidikan dasar di Jepang. Lesson Study merupakan terjemahan dari bahasa Jepang jugyokenkyu, yang berasal dari dua kata jugyo yang berarti lesson dan kenkyu yang berarti study. Menurut Lewis (2002) Lesson Study di Jepang tidak hanya memberikan sumbangan terhadap pengetahuan keprofesionalan guru, tetapi juga terhadap peningkatan sistem pendidikan yang lebih luas. Keberhasilan Jepang dalam mengembangkan Lesson Study ini mulai diikuti oleh Negara lain, salah satunya adalah Indonesia.

Stigler dan Hiebert (1999) mengidentifikasikan beberapa faktor yang membuat lesson study bisa meningkatkan kualitas pendidikan Jepang:

1) Lesson study didasarkan pada model peningkatan pembelajaran yang sifatnya terus-menerus sekalipun peningkatan yang dicapai melalui satu kegiatan lesson study hanya kecil saja, namun karena kegiatan dilaksanakan terus-menerus maka peningkatan ini menjadi besar.

2) Lesson study selalu memfokuskan pada bagaimana membuat murid belajar.

3) Lesson study memfokuskan pada peningkatan yang bisa langsung memanfaatkan dalam konteks yang ada.
4) Lesson study merupakan sebuah kolaborasi. Dengan melakukan kolaborasi para guru bisa saling langsung bertukar pikiran dan saling memberi masukan untuk meningkatkan kualitas pembelajaran.

5) Guru yang terlibat dalam lesson study merasa bahwa mereka memberikan kontribusi terhadap ilmu mengajar dan juga terhadap perkembangan profesionalisme dirinya. Oleh karena itu lesson study bukan hanya mengembangkan profesionalisme guru tetapi juga mengembangkan ilmu tentang mengajar.

\section{Study Literatur}

\subsection{Lesson Study}

Pengertian Lesson Study menurut Styler dan Hiebert (Susilo, 2009:3) adalah suatu proses kolaboratif pada sekelompok guru ketika mengidentifikasikan masalah pembelajaran, merancang suatu skenario pembelajaran (yang meliputi kegiatan mencari buku dan artikel mengenai topik yang akan diajarkan); membelajarkan peserta didik sesuai dengan skenario (salah seorang guru melaksanakan pembelajaran sedangkan yang lain mengamati), mengevaluasi dan merevisi skenario pembelajaran, membelajarkan lagi skenario pembelajaran yang telah direvisi, mengevaluasi lagi pembelajaran dan membagikan hasilnya dengan guru-guru lain (mendiseminasikannya).

Berdasarkan hasil observasi terhadap beberapa sekolah di Jepang, Lewis (2004) mengemukakan tentang ciri-ciri esensial dari Lesson Study, yaitu: (1) Tujuan bersama untuk jangka panjang, (2) Materi pelajaran yang penting, (3) Studi tentang siswa secara cermat, (4) Observasi pembelajaran secara langsung.

Lewis (2002), menyebutkan enam tahapan dalam lesson study, yaitu (1) membentuk kelompok lesson study, (2) memfokuskan lesson 
study, (3) merencanakan rencana pembelajaran, (4) melaksanakan pembelajaran di kelas, (5) mendiskusikan dan menganalisis pembelajaran yang telah dilakukan, dan (6) merefleksikan pembelajaran dan merencanakan tahap-tahap selanjutnya.

Enam langkah Lesson Study menurut Lewis tersebut dapat kita rinci menjadi 3 tahapan, yaitu: 1) Tahap Plan, yaitu membuat perencanaan pembelajaran secara kolaboratif, 2) Tahap Do, yaitu penerapan rencana pembelajaran di kelas oleh seorang guru model sedangkan yang lain mengamati aktivitas siswa dalam pembelajaran, 3) Tahap See, yaitu diskusi setelah pembelajaran untuk merefleksikan efektivitas pembelajaran untuk perbaikan. Adapun tahapan Lesson Study dapat dilihat pada Gambar 1 berikut ini:

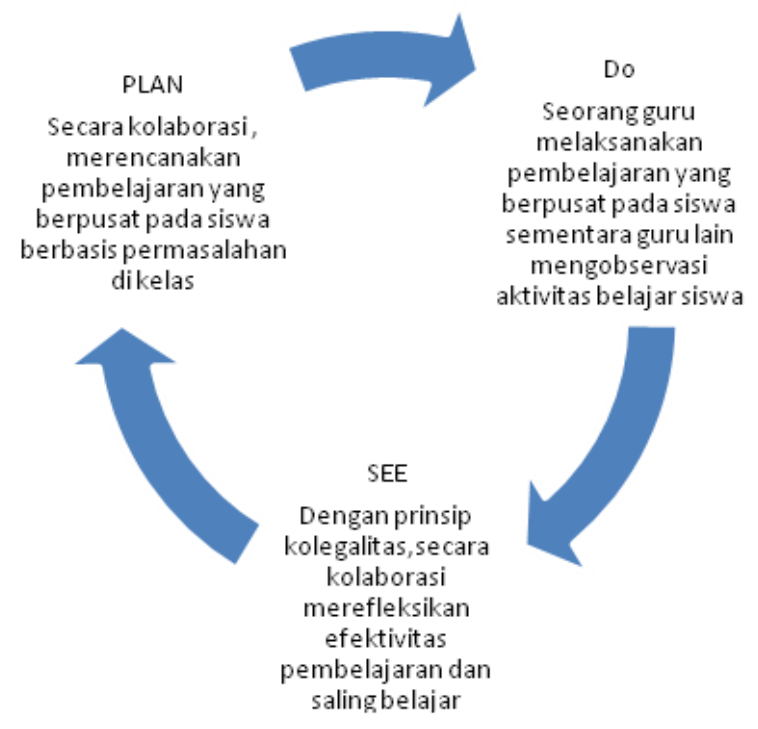

Gambar 1. Tahapan Lesson Study

\subsection{Hasil Belajar}

Belajar bukan hanya kegiatan siswa untuk menghafal tetapi belajar adalah suatu proses dimana terjadinya perubahan pada diri seseorang. Menurut Sudjana (1989) perubahan sebagai hasil proses belajar dapat ditunjukkan dalam berbagai bentuk seperti berubah pengetahuannya, pemahamannya, sikap dan tingkah lakunya, keterampilannya, kecakapan dan kemampuannya, daya reaksinya, daya penerimaannya, dan lain-lain aspek individu.

Hasil belajar menurut Anggraeni (2008:15) adalah pengetahuan, keterampilan, serta nilai dan sikap yang diperoleh setelah terjadi interaksi dengan sumber belajar. Selanjutnya Bloom (Sukardi, 2008:75) menyatakan bahwa tujuan belajar diarahkan untuk mencapai ketiga ranah (domain), yaitu: ranah kognitif, afektif dan psikomotor. Ranah kognitif menekankan pada aspek intelektual, seperti pengetahuan, pengertian dan keterampilan berpikir. Ranah afektif menekankan pada aspek perasaan dan emosi seperti minat, sikap, apresiasi dan cara penyesuaian diri. Ranah psikomotor menekankan pada aspek keterampilan motorik dan manipulasi data atau obyek.

Hasil belajar dapat dipengaruhi oleh faktor internal, yaitu faktor yang berasal dari dalam diri siswa dan faktor ekternal, yaitu faktor yang berasal dari luar diri siswa. Hal ini sejalan dengan pendapat Slameto (2003) yang mengungkapkan faktor-faktor yang mempengaruhi hasil belajar siswa antara lain:

1) Faktor internal, yaitu faktor yang berasal dari dalam diri siswa sendiri yang meliputi faktor jasmaniah, psikologis dan kelelahan.

2) Faktor ekstern, yaitu faktor yang berasal dari luar diri siswa sendiri yang meliputi faktor keluarga, faktor sekolah, dan faktor masyarakat.

\section{Metode Penelitian}


Penelitian ini dilakukan dengan pendekatan kualitatif dengan melakukan pengamatan terhadap tindakan mahasiswa pada saat kegiatan pembelajaran di kelas. Penelitian ini dilaksanakan pada Program Studi Pendidikan Matematika STKIP Siliwangi Bandung. Sampel yang dijadikan penelitian adalah mahasiswa kelas A2 2014 Reguler yang berjumlah 41 mahasiswa. Penelitian ini dilakukan sebanyak empat siklus, dimana setiap siklus terdiri dari tiga tahap yaitu plan, do, dan see.

Untuk mendapatkan data dalam penelitian ini dilakukan observasi dan tes. Observasi dilakukan dengan melakukan pengamatan terhadap tindakan mahasiswa pada saat kegiatan pembelajaran di kelas, yaitu pada saat melaksanakan tahapan perencanaan, pelaksanaan, dan refleksi. Sedangkan tes dilakukan pada setiap siklus setelah kegiatan Lesson Study selesai dilaksanakan. Tes ini diberikan untuk mengetahui hasil belajar yang diperoleh mahasiswa setelah mendapatkan pembelajaran dengan Lesson Study.

Analisis data yang digunakan dalam penelitian ini adalah analisis kualitatif yang terdiri dari reduksi data, penyajian data dan penarikan kesimpulan.

\section{Hasil Penelitian dan Pembahasan 4.1. Hasil Pelaksanaan Siklus I}

Pada siklus I yang dilaksanakan pada tanggal 3 Maret 2015 dengan materi Bilangan, mahasiswa secara berkelompok melakukan tahap plan. Tahap plan ini dimulai dengan membuat chapter design dari materi bilangan. Dalam chapter design ini, mahasiswa melihat sistematika dan kedalaman materi, apakah sudah sesuai atau belum, serta menentukan jumlah pertemuan untuk materi tersebut. Kemudian chapter design tersebut dipresentasikan sehingga terjadi diskusi antar tiap kelompok sehingga disepakati chapter design yang akan digunakan. Selanjutnya mahasiswa membuat lesson design yaitu menyusun langkah-langkah pembelajaran sesuai dengan chapter design yang telah disepakati. Tahap selanjutnya adalah tahap do, yaitu open lesson dimana salah satu kelompok menjadi guru model, satu kelompok menjadi observer, dan kelompok lainnya menjadi siswa. Tahap do dilaksanakan pada tanggal 10 Maret 2015. Tahap terakhir yaitu tahap see, dimana para observer memberikan masukan mengenai penampilan guru model. Pada siklus I ini diperoleh hasil bahwa pembelajaran yang dilakukan oleh guru model belum sesuai dengan langkah-langkah pembelajaran yang telah mereka susun. Selain itu, guru model belum bisa mengatur waktu sehingga waktu yang telah mereka alokasikan untuk materi ini tidak cukup. Kelompok yang menjadi siswa pun tidak terlibat aktif dalam kegiatan pembelajaran. Masih ada mahasiswa yang melamun, bahkan mengobrol dengan temannya.

\subsection{Hasil Pelaksanaan Siklus II}

Siklus II dilaksanakan pada tanggal 17 Maret 2015 dengan materi Himpunan. Tahapan pada siklus tahap II sama dengan tahapan pada siklus I, yaitu dimulai dengan tahap plan. Pada tahap plan mahasiswa secara berkelompok membuat chapter design materi himpunan dengan melihat sistematika dan kedalaman materi serta menentukan jumlah pertemuan untuk materi himpunan tersebut. Chapter design tersebut dipresentasikan dan didiskusikan kemudian dibuat lesson design berdasarkan kesepakan yang telah diperoleh dari hasil diskusi. Tahap do dilaksanakan pada tanggal 24 Maret 2015, dimana satu kelompok menjadi guru model, satu kelompok menjadi observer dan kelompok lainnya menjadi siswa. Selanjutnya pada tahap see diperoleh masukan-masukan dari para observer diantaranya yaitu guru model belum 
bisa menguasai kelas dan kurang menguasai materi tetapi langkah-langkah pembelajaran yang guru model lakukan sudah sesuai dengan yang mereka susun. Pada siklus II ini, hasil belajar siswa belum terlihat peningkatannya.

\subsection{Hasil Pelaksanaan Siklus III}

Siklus III dilaksanakan pada tanggal 7 April 2015 dengan materi Bangun Datar. Pada siklus III ini, mahasiswa sudah mulai terbiasa dengan tahapan-tahapan lesson study. Dimulai dari tahap plan, yaitu membuat chapter dan lesson design materi bangun datar dilanjutkan dengan tahap do, yaitu open lesson yang dilaksanakan tanggal 21 April 2015 dan diakhiri dengan tahap see, dimana pada siklus III ini observer tidak terlalu banyak memberikan masukan-masukan, karena guru model pada siklus III ini sudah lebih baik dibandingkan siklus I dan II, hanya masih ada mahasiswa yang berperan menjadi siswa tidak memperhatikan penjelasan dari guru model. Pada siklus ini masih terdapat kekurangan-kekurangan sehingga diperlukan perbaikan pada siklus selanjutnya.

\subsection{Hasil Pelaksanaan Siklus IV}

Berdasarkan hasil dari siklus III, maka dilakukan beberapa perbaikan pada siklus IV. Siklus IV dilaksanakan pada tanggal 5 Mei 2015 dengan materi Persamaan Garis Lurus. Seperti pada siklus I-III, tahapan siklus IV ini dimulai dari tahap plan, yaitu membuat chapter dan lesson design materi persamaan garis lurus. Selanjutnya tahap do dilakukan pada tanggal 12 Mei 2015. Pada siklus IV ini, guru model menggunakan model pembelajaran yang cukup menarik sehingga mahasiswa yang berperan sebagai siswa sangat antusias mengikuti kegiatan pembelajaran. Pada tahap see, observer pun memberikan respon yang positif terhadap guru model pada siklus IV ini.
Berdasarkan analisis data yang diperoleh dari hasil tes dan observasi dari siklus I sampai siklus IV diperoleh hasil yang menunjukkan adanya peningkatan hasil belajar mahasiswa. Peningkatan hasil belajar mahasiswa tersebut dapat dilihat pada Gambar 2 berikut ini.

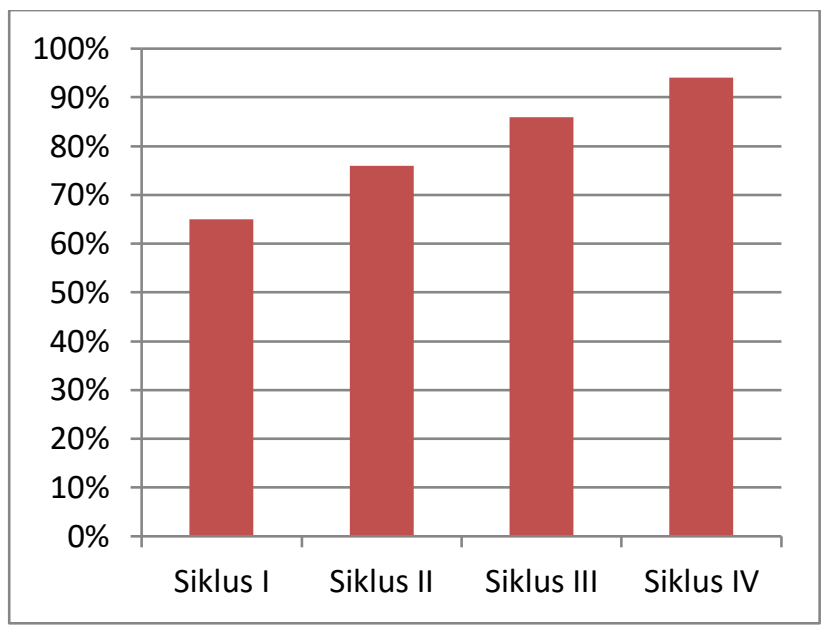

\section{Gambar 2. Peningkatan Hasil Belajar Mahasiswa}

Berdasarkan gambar di atas, terlihat peningkatan hasil belajar mahasiswa mulai dari siklus I sampai dengan siklus IV. Peningkatan hasil belajar ini tidak terlepas dari pelaksanaan Lesson Study pada proses pembelajaran di kelas. Pada awalnya mahasiswa tidak terlibat aktif saat proses pembelajaran, tetapi dengan motivasi dan bimbingan dari dosen maka mahasiswa menjadi lebih aktif. Mahasiswa pun menjadi lebih antusias saat proses pembelajaran, karena mereka dapat mengeluarkan ide-ide yang mereka miliki saat merencanakan langkahlangkah pembelajaran, selain itu mereka lebih menguasai konsep-konsep matematika SMP karena mereka terjun langsung dalam menyiapkan materi yang akan mereka tampilkan pada saat open lesson.

Pada setiap siklus memang masih ditemukan kekurangan-kekurangan, tetapi mahasiswa yang 
berperan sebagai guru model beserta mahasiswa lainnya mampu mencari cara untuk memperbaiki kekurangan-kekurangan tersebut sehingga pada siklus terakhir yaitu siklus ke IV tidak ditemukan lagi kekurangan-kekurangan seperti pada siklus sebelumnya.

\section{Kesimpulan dan Saran}

\subsection{Kesimpulan}

Berdasarkan hasil analisis data yang telah dilakukan maka diperoleh kesimpulan bahwa implementasi Lesson Study pada mata kuliah Kapita Selekta Matematika SMP dapat meningkatkan hasil belajar mahasiswa.

\subsection{Saran}

Berdasarkan kesimpulan di atas, maka peneliti mengemukakan beberapa saran sebagai berikut:

1) Pembelajaran dengan Lesson Study ini dapat dijadikan sebagai salah satu alternatif pembelajaran bagi para calon guru

2) Sebaiknya dilakukan penelitian lanjutan mengenai Lesson Study untuk meningkatkan hasil belajar mahasiswa pada pokok bahasan lain dengan subjek yang berbeda.

\section{DAFTAR PUSTAKA}

Anggraeni, R. (2008). Pembelajaran Cooperative (Kelompok Kecil) untuk Meningkatkan Kecerdasan Emosional dan Hasil Belajar Siswa. Makalah Seminar Matematika FPMIPA UPI Bandung: Tidak Diterbitkan.

Lewis, C.C. (2002). Lesson study: A Handbook of Teacher-Led Instructional Change. Philadelphia: Reseach For better School .Inc

Slameto. (2003). Belajar dan Faktor-Faktor yang Mempengaruhinya. Jakarta: PT Rineka Cipta.

Stigler, J. W., \& Hibert, J. (1999). The Teaching Gap : Best Ideas from The World's Teachers for Improving Education in the Classroom. New York: the free Press.

Sukardi. (2008). Metodologi Penelitian Pendidikan, Kompetensi dan Praktiknya. Jakarta : PT. Bumi Aksara.

Susilo, H. et. al. (2009). Lesson Study Berbasis Sekolah. Malang: Bayu Media. 